\title{
LITERATURE REVIEW PENGARUH SENAM LANSIA TERHADAP PENURUNAN TEKANAN DARAH PADA PENDERITA HIPERTENSI
}

\author{
Erida Fadila $^{1^{*}}$, Ela Sri Solihah ${ }^{2}$ \\ ${ }^{1,2}$ STIKes Ahmad Dahlan Cirebon \\ Email Korespondensi: erida.fadila@gmail.com \\ Disubmit: 03 Januari 2022 Diterima: 31 Januari 2022 Diterbitkan: 02 Februari 2022 \\ DOI: https://doi.org/10.33024/mnj.v5i2.6032
}

\section{ABSTRACT: LITERATURE REVIEW EFFECT OF ELDERLY EXERCISE ON BLOOD PRESSURE REDUCTION IN HYPERTENSION PATIENTS}

Background: Hypertension is an increase in blood pressure that exceeds normal limits and occurs continuously due to an imbalance of several risk factors. The number of people with hypertension is still quite high, especially in the elderly according to the 2018 National Riskesdas Report, namely at the age of 60 to 75 years and over (69.53\%) and more dominated by women (36.85\%) compared to men (31.34). \%). One of the non-pharmacological techniques that are effective in lowering blood pressure is with elderly exercise, because the elderly exercise can help relax the muscles of the blood vessels so that there is dilation in them which results in a decrease in blood pressure.

The purpose of this literature review: to determine the effect of elderly exercise on reducing blood pressure in patients with hypertension.

Research Methods: The search for article data sources was carried out through an inclusion study design using a Literature Review.

Results: the analysis of journal reviews there is a difference in the level of effectiveness between elderly exercise (50\%) with walking therapy (5\%) and hypertension (45\%) where elderly exercise is more influential than walking therapy in lowering blood pressure.

Conclusion: There is an effect of elderly exercise on reducing blood pressure in patients with hypertension.

Keywords : Elderly, elderly gymnastics, hypertension

\section{INTISARI: LITERATURE REVIEW PENGARUH SENAM LANSIA TERHADAP PENURUNAN TEKANAN DARAH PADA PENDERITA HIPERTENSI}

Latar Belakang : Hipertensi merupakan peningkatan tekanan darah yang melebihi batas normal dan terjadi secara terus menerus yang disebabkan karena ketidakseimbangan beberapa faktor risiko. Angka penderita hipertensi masih cukup tinggi terutama pada usia lansia menurut Laporan Nasional Riskesdas 2018 yaitu pada usia 60 sampai 75 tahun lebih $(69,53 \%)$ dan lebih di dominasi oleh perempuan $(36,85 \%)$ dibanding dengan laki-laki $(31,34 \%)$.Salah satu teknik non farmakologi yang efektif menurunkan tekanan darah yaitu dengan senam lansia, karena gerakan senam lansia dapat membantu melemaskan otot pembuluh darah sehingga terjadi pelebaran di dalamnya yang mengakibatkan penurunan tekanan darah. 
Tujuan dari literature review ini : untuk mengetahui pengaruh senam lansia terhadap penurunan tekanan darah pada penderita hipertensi.

Metode Penelitian : Pencarian sumber data artikel dilakukan melalui inklusi study design menggunakan Literature Review.

Hasil : analisis review jurnal terdapat perbedaan tingkat efektifitas antara senam lansia (50\%) dengan terapi jalan kaki (5\%) dan hipertensi $(45 \%)$ dimana senam lansia lebih berpengaruh dibandingkan terapi jalan kaki dalam menurunkan tekanan darah.

Kesimpulan : Terdapat pengaruh senam lansia terhadap penurunan tekanan darah pada penderita hipertensi.

Kata kunci : Lansia, senam lansia, hipertensi

\section{PENDAHULUAN}

Menurut WHO tahun 2015 hipertensi adalah salah satu penyebab utama kematian dini di seluruh dunia. Diperkirakan pada tahun 2020, sekitar 1,56 miliar usia dewasa mengalami hipertensi. Setiap tahun hamper 8 miliarorangdi duniadan1,5 juta di kawasan Asia Timur-Selatan meninggal karena hipertensi. Di kawasan Asia TimurSelatan, hampir sepertiga dari usia dewasa menderita hipertensi. (Sartika \& Vebi, 2020).

Gangguan sistem kardiovaskular menjadi masalah kesehatan utama baik di negara maju maupun negara berkembang. Setiap tahunnya, hipertensi menjadi penyebab kematian nomor satu di dunia. Hipertensi merupakan penyakit kardiovaskular yang paling banyak ditemui di masyarakat (Kemenkes RI, 2019).

Data World Health Organization (WHO) menunjukkan sekitar 1,13 miliar orang di dunia menderita hipertensi, artinya 1 dari 3 orang di dunia telah terdiagnosa hipertensi. Jumlah penyandang hipertensi meningkat setiap tahunnya, diperkirakan ada 1,5 miliar orang yang akan terkena hipertensi pada tahun 2025, dan diperkirakan 9,4 juta orang meninggal setiap tahunnya akibat hipertensi dan komplikasinya(WHO (2015) dalam Kemenkes RI, (2019).
Prevalensi Hipertensi berdasarkan Hasil Pengukuran pada Penduduk Umur $\geq 18$ Tahun menurut Provinsi, Riskesdas 2018. Hipertensi di Indonesia merupakan masalah kesehatan dengan prevalensi tertinggi yaitu (44\%) di Kalimantan Selatan diikuti di Jawa Barat (39,60\%). Penyakit hipertensi adalah penyakit dengan jumlah tertinggi yang diderita oleh lansia, yaitu pada umur 45-54 tahun sekitar 45,32\%, umur 55-64 tahun sekitar 55,23\%, umur 65-74 tahun sekitar $63,22 \%$ dan umur diatas 75 tahun mencapai 69,53\%(Riskesdas, 2018). Seseorang dinyatakan mengalami penyakit hipertensi bila tekanan sistolik mencapai di atas $140 \mathrm{mmHg}$ dan tekanan diastolik di atas $90 \mathrm{mmHg}$ (Junaidi, (2010) dalam jurnal Hasanudin et al., (2018).

Hipertensi dapat dihindari dengan menghindari faktor resiko dan mencegahnya dengan beberapa upaya yaitu menerapkan pola hidup sehat dengan melakukan aktivitas fisik secara teratur, kebutuhan tidur yang cukup, pikiran yang rileks dan santai, menghindari kafein, rokok, alkohol, dan stress, kemudian menerapkan pola makan yang sehat dengan menghindari atau mengurangi makanan yang mengandung lemak tinggi, tinggi kalori, berminyak, kolesterol, santan, garam berlebihan, dan penggunaan kadar gula 
tinggi(Widianti \& Atika (2010) dalam jurnal Eviyanti, (2020)). Jenis latihan fisik (olahraga) yang bisa dilakukan lansia antara lain adalah senam lansia. Senam lansia adalah serangkaian gerak nada yang teratur dan terarah serta terencana yang diikuti oleh orang lanjut usia dalam bentuk latihan fisik yang berpengaruh terhadap kemampuan fisik lansia. Aktivitas olahraga ini akan membantu tubuh agar tetap bugar dan tetap segar karena melatih tulang tetap kuat dan membantu menghilangkan radikal bebas yang berkeliaran dalam tubuh (Eti, L (2015) dalam jurnal Eviyanti, (2020)).

Berdasarkan penelitian Eviyanti (2020) terdapat pengaruh senam

\section{METODOLOGI PENELITIAN}

PICOS Framework yang digunakan dalam strategi mencari jurnal tersebut. yang akan menganalisis masalah hipertensi
a. Population/problem: Populasi intervensi atau penatalaksanaan pada kasus yang terjadi yaitu dengan terapi non farmakologi senam lansia.
b. Intervention: Tindakan
c. Comparation: Pembanding dari terapisenam lansia dengan terapi jalan kaki

lansia terhadap penurunan tekanan darah sistolik dan diastolik pada lansia hipertensi di BPSTW unit Abiyoso Yogyakarta. Dalam penelitian lain juga ada pengaruh senam lansia terhadap penurunan tekanan darah lansia penderita hipertensi yang dilakukan oleh Tulak \& Munawira pada tahun 2017.

Dilihat dari gambaran latar belakang atau fenomena diatas, angka penderita hipertensi masih tinggi terutama pada usia lansia maka penulis tertarik dalam menganalisis fenomena tersebut yang akan dilihat dengan tinjauan Literature Review dengan tema "Pengaruh Senam Lansia Terhadap Penurunan Tekanan Darah Pada Penderita Hipertensi”.

d. Outcome: Pengaruh dari senam lansia terhadap penurunan tekanan darah

e. Study design: Menggunakan desain Pre eksperiment, quasi eksperiment dan Cross Sectional

Dalam pencarian jurnal menggunakan kata kunci (AND, OR NOT or AND NOT) yang dipakai untuk lebih detail lagi dalam pencarian jurnal dan dapat mempermudah pencarian jurnal yang digunakan. Kata kunci yang digunakan adalah "Senam lansia" AND "Hipertensi” AND “Lansia”. 


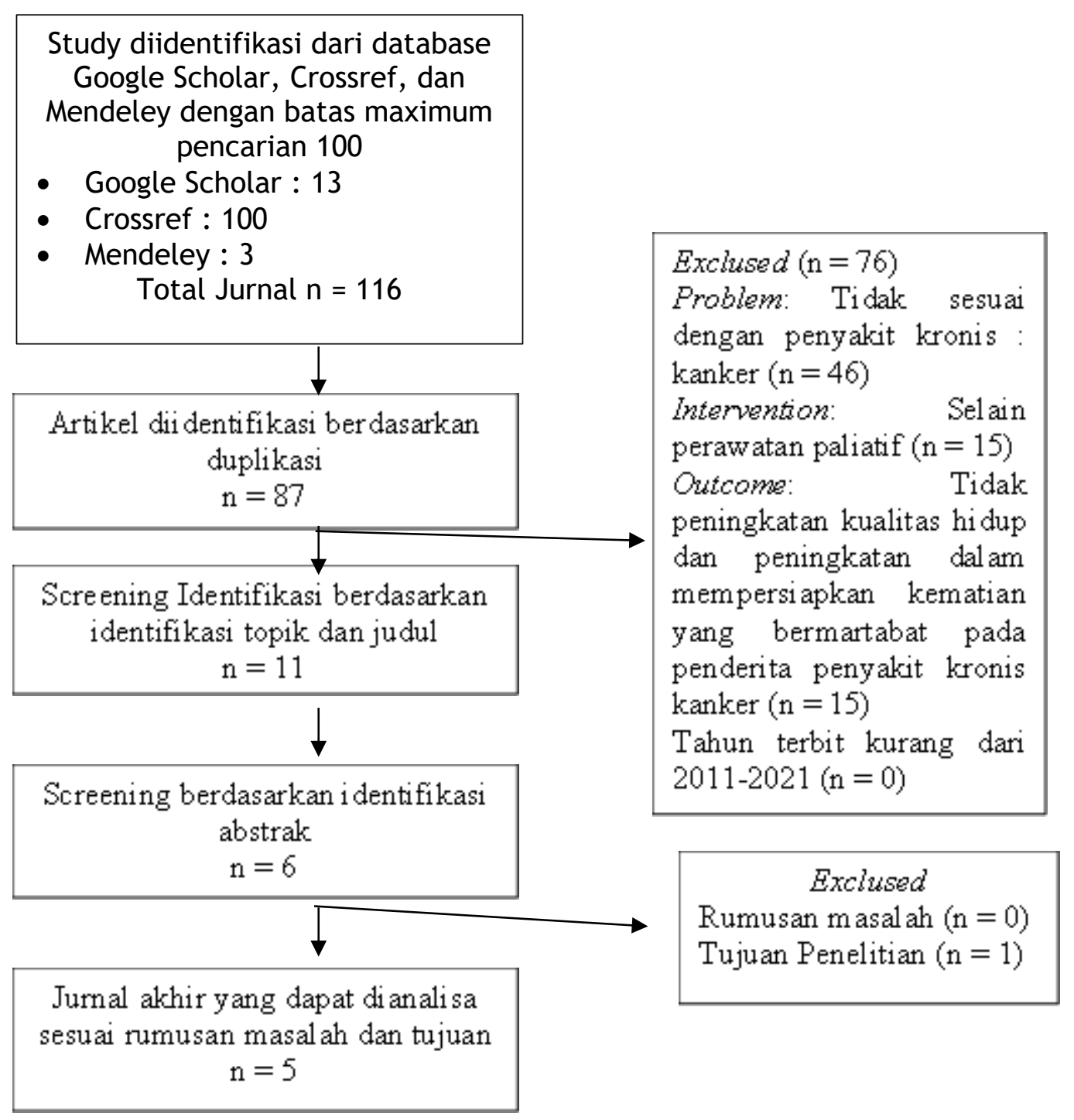

Bagan 2. 1 Alur Literatur Review 
HASIL

Karakteristik Umum Literature

Tampilan hasil literatur review dalam tugas akhir literature review berisi tentang ringkasan dan pokokpokok hasil dari setiap artikelyang

terpilih dalam bentuk tabel, kemudian dibawah bagian tabel dijabarkan apa yang ada didalam tabel tersebut berupa makna dan tren dalam bentuk paragraf.

\section{Tabel 1 Karakteristik Umum Literatur}

\begin{tabular}{|c|c|c|c|}
\hline No & Kategori & $f$ & $\%$ \\
\hline A & Tahun Publikasi & & \\
\hline 1 & 2013 & 1 & 5 \\
\hline 2 & 2015 & 2 & 10 \\
\hline 3 & 2016 & 1 & 5 \\
\hline 4 & 2017 & 5 & 25 \\
\hline 5 & 2018 & 1 & 5 \\
\hline 6 & 2019 & 6 & 30 \\
\hline 7 & 2020 & 2 & 10 \\
\hline 8 & 2021 & 2 & 10 \\
\hline & Jumlah & 20 & 100 \\
\hline B & Desain Penelitian & & \\
\hline 1 & $\begin{array}{l}\text { Pre Experimental - One Group } \\
\text { pretest and post test design }\end{array}$ & 14 & 70 \\
\hline 2 & Quasi Experiment & 4 & 20 \\
\hline 3 & $\begin{array}{l}\text { Desain Analitik dengan Cross } \\
\text { Sectional }\end{array}$ & 2 & 10 \\
\hline & Jumlah & 20 & 100 \\
\hline $\mathrm{C}$ & Sampling penelitian & & \\
\hline 1 & Purposive Sampling & 10 & 50 \\
\hline 2 & Simple Random Sampling & 3 & 15 \\
\hline 3 & $\begin{array}{l}\text { Total Sampling/Sampling } \\
\text { Jenuh }\end{array}$ & 5 & 25 \\
\hline 4 & $\begin{array}{l}\text { Non Probability Sampling } \\
\text { dengan teknik Accidental } \\
\text { Sampling }\end{array}$ & 2 & 10 \\
\hline & Jumlah & 20 & 100 \\
\hline D & Instrumen penelitian & & \\
\hline 1 & Sphygmomanometer & 9 & 45 \\
\hline 2 & $\begin{array}{l}\text { Sphygmomanometer } \\
\text { \&Stethoscope }\end{array}$ & 2 & 10 \\
\hline 3 & $\begin{array}{l}\text { Sphygmomanometer\& Lembar } \\
\text { Observasi }\end{array}$ & 5 & 25 \\
\hline
\end{tabular}

Berdasarkan dari hasil analisis literature review 20 jurnal yang dilakukan, sebagian besar (30\%) menggunakan jurnal yang diterbitkan tahun 2019 dengan menggunakan desain penelitian Pre Eksperimental - One Group pre test and post test design sebesar (70\%). Sampling penelitian literature review yang telah peneliti lakukansetengahnya (50\%) menggunakan teknik Purposive Sampling, sebagian besar (45\%) menggunakan instrumen Sphygmomanometer dan sebagian kecil (20\%) menggunakan analisis Uji Statistik Paired Sample t-test. 


\section{Karakteristik Hasil Penelitian}

Tabel 2 Karakteristik Hasil Penelitian

\begin{tabular}{clcc}
\hline No & \multicolumn{1}{c}{ Kategori } & F & $\%$ \\
\hline A & Jenis Terapi non farmakologi & & \\
1 & Senam lansia & 10 & 50 \\
2 & Terapi jalan kaki & 1 & 5 \\
B & Tekanan Darah & & \\
1 & Hipertensi & 9 & 45 \\
\hline \multicolumn{1}{c}{ Jumlah } & $\mathbf{2 0}$ & $\mathbf{1 0 0}$ \\
\hline
\end{tabular}

Berdasarkan dilakukannya literature review dari 20 jurnal terdapat 11 jurnal yang termasuk ke dalam jenis terapi non farmakologi dan 9 jurnal yang termasuk ke dalam kategori tekanan darah dengan hampir setengahnya menggunakan jenis terapi non farmakologi senam lansia sebesar (50\%) dan persentase terkecil menggunakan jenis terapi non farmakologi jalan kaki sebesar $(5 \%)$.

\section{Analisis Penelitian}

\section{Pengaruh Senam Lansia terhadap Penurunan Tekanan Darah pada Penderita Hipertensi}

\begin{tabular}{|c|c|c|c|}
\hline No & Variabel yang diteliti & Analisis Literatur & $\begin{array}{l}\text { Sumber } \\
\text { Empiris }\end{array}$ \\
\hline 1. & $\begin{array}{l}\text { Variabel independen (bebas) } \\
\text { adalah senam lansia } \\
\text { Variabel dependen (terikat) } \\
\text { adalah tekanan darah }\end{array}$ & $\begin{array}{l}\text { Ada hubungan kerutinan senam } \\
\text { lansia dengan tekanan darah lansia } \\
\text { penderita hipertensi Di Posyandu } \\
\text { Widodo Makmur Wilayah Kerja } \\
\text { Puskesmas Demangan Kota Madiun }\end{array}$ & $\begin{array}{l}\text { Euis Liawati (2013) } \\
\text { Vol.26 No.4 }\end{array}$ \\
\hline 2. & $\begin{array}{l}\text { Variabel independen (bebas) } \\
\text { adalah senam lansia } \\
\text { Variabel dependen (terikat) } \\
\text { adalah penurunan tekanan } \\
\text { darah }\end{array}$ & $\begin{array}{l}\text { Terdapat pengaruh senam lansia } \\
\text { terhadap penurunan tekanan darah } \\
\text { pada lansia hipertensi di PSTW } \\
\text { Budi Sejahtera Martapura }\end{array}$ & $\begin{array}{l}\text { M. Noor Ifansyah, } \\
\text { Herawati, Noor Diani } \\
(2015) \\
\text { Vol.3 No. } 1\end{array}$ \\
\hline 3. & $\begin{array}{l}\text { Variabel independen (bebas) } \\
\text { adalah senam lansia dan } \\
\text { variabel dependen (terikat) } \\
\text { adalah tekanan darah }\end{array}$ & $\begin{array}{l}\text { Ada hubungan senam lansia dengan } \\
\text { tekanan darah pada lansiaDi } \\
\text { Puskesmas Kebonsari Surabaya }\end{array}$ & $\begin{array}{l}\text { Diyah Pratiwi \& Nety } \\
\text { Mawarda } \\
\text { Hatmanti (2015) } \\
\text { Vol.6 No.2 }\end{array}$ \\
\hline 4. & $\begin{array}{l}\text { Variabel independen (bebas) } \\
\text { adalah senam lansia } \\
\text { Variabel dependen (terikat) } \\
\text { adalah kestabilan tekanan } \\
\text { darah }\end{array}$ & $\begin{array}{l}\text { Senam lansia efektif terhadap } \\
\text { kestabilan tekanan darah pada } \\
\text { lansia di Panti Wredha Santo } \\
\text { Yoseph Kediri }\end{array}$ & $\begin{array}{l}\text { Srinalesti Mahanani } \\
\text { \&Erlin Kurnia (2016) } \\
\text { Vol.9 No.2 }\end{array}$ \\
\hline 5. & $\begin{array}{l}\text { Variabel independen (bebas) } \\
\text { adalah senam lansia } \\
\text { Variabel dependen (terikat) } \\
\text { adalah tekanan darah }\end{array}$ & $\begin{array}{l}\text { Ada pengaruh senam lansia } \\
\text { terhadap tekanan darah diastolik } \\
\text { pada lansia dengan hipertensi Di } \\
\text { Panti Sosial Tresna Werdha Budi } \\
\text { Luhur Jambi }\end{array}$ & $\begin{array}{l}\text { M. Dody Izhar (2017) } \\
\text { Vol.17 No.1 }\end{array}$ \\
\hline
\end{tabular}




\begin{tabular}{|c|c|c|c|}
\hline 6. & $\begin{array}{l}\text { Variabel independen (bebas) } \\
\text { adalah senam hipertensi lansia } \\
\text { Variabel dependen (terikat) } \\
\text { adalah penurunan tekanan } \\
\text { darah }\end{array}$ & $\begin{array}{l}\text { Terdapat pengaruh senam } \\
\text { hipertensi terhadap tekanan darah } \\
\text { lansiadi Panti Wreda Darma Bhakti } \\
\text { Kelurahan Pajang Surakarta }\end{array}$ & $\begin{array}{l}\text { Totok Hernawan, } \\
\text { Fahrun Nur Rosyid } \\
\text { (2017) } \\
\text { Vol.10 No.1 }\end{array}$ \\
\hline 7. & $\begin{array}{l}\text { Variabel independen (bebas) } \\
\text { adalah senam lansia } \\
\text { Variabel dependen (terikat) } \\
\text { adalah tekanan darah }\end{array}$ & $\begin{array}{l}\text { Ada pengaruh senam lansia } \\
\text { terhadap penurunan tekanan } \\
\text { darahDi Puskesmas Wara Palopo }\end{array}$ & $\begin{array}{l}\text { Grace Tedy Tulak \& } \\
\text { Munawira Umar } \\
\text { (2017) } \\
\text { Vol.2 No.1 }\end{array}$ \\
\hline 8. & $\begin{array}{l}\text { Variabel independen (bebas) } \\
\text { adalah senam } \\
\text { Variabel dependen (terikat) } \\
\text { adalah tekanan darah lansia }\end{array}$ & $\begin{array}{l}\text { Terdapat pengaruh antara senam } \\
\text { dan tekanan darah di Panti Sosial } \\
\text { Tresna Werdha Budi Sejahtera } \\
\text { Banjarbaru }\end{array}$ & $\begin{array}{l}\text { Rai Sinta, } \\
\text { Sri Mulyani, Luckyta } \\
\text { Ibna Permana (2017) } \\
\text { Vol.28 }\end{array}$ \\
\hline 9. & $\begin{array}{l}\text { Variabel independen (bebas) } \\
\text { adalah senam anti hipertensi } \\
\text { lansia } \\
\text { Variabel dependen (terikat) } \\
\text { adalah tekanan darah lansia }\end{array}$ & $\begin{array}{l}\text { Terdapat pengaruh senam anti } \\
\text { hipertensi terhadap tekanan darah } \\
\text { lansia di Desa Kemuningsari Lor } \\
\text { Kecamatan Panti Kabupaten } \\
\text { Jember }\end{array}$ & $\begin{array}{l}\text { Misbakhul Anwari, } \\
\text { Rita Vidyawati,dkk } \\
(2018) \\
\text { Edisi khusus }\end{array}$ \\
\hline 10. & $\begin{array}{l}\text { Variabel independen (bebas) } \\
\text { adalah senam lansia } \\
\text { Variabel dependen (terikat) } \\
\text { adalah hipertensi }\end{array}$ & $\begin{array}{l}\text { Ada pengaruh senam lansia } \\
\text { terhadap tekanan darah pada } \\
\text { pasien hipertensi di Puskesmas } \\
\text { Somba Opu Kab.Gowa } \\
\end{array}$ & $\begin{array}{l}\text { Hasliani Yustiana \& } \\
\text { Sri (2019) } \\
\text { Vol.9 No.2 }\end{array}$ \\
\hline 11. & $\begin{array}{l}\text { Variabel independen (bebas) } \\
\text { adalah senam hipertensi lansia } \\
\text { Variabel dependen (terikat) } \\
\text { adalah tekanan darah lansia }\end{array}$ & $\begin{array}{l}\text { Ada pengaruh yang signifikan } \\
\text { senam hipertensi lansia terhadap } \\
\text { tekanan darah lansia dengan } \\
\text { hipertensiDi Wilayah Kerja } \\
\text { Puskesmas Cakranegara Kelurahan } \\
\text { Turida }\end{array}$ & $\begin{array}{l}\text { Ni Putu Sumartini, } \\
\text { Zulkifli, } \\
\text { Made Anandam } \\
\text { Prasetya Adhitya } \\
\text { (2019) } \\
\text { Vol.1 No.2 }\end{array}$ \\
\hline 12. & $\begin{array}{l}\text { Variabel independen (bebas) } \\
\text { adalah perbedaan jalan kaki \& } \\
\text { senam lansia } \\
\text { Variabel dependen (terikat) } \\
\text { adalah tekanan darah }\end{array}$ & $\begin{array}{l}\text { Terdapat perbedaan antara jalan } \\
\text { kaki dengan senam lansia terhadap } \\
\text { tekanan darah lansia hipertensi di } \\
\text { UPTD PSRLU Ciparay Kabupaten } \\
\text { Bandung }\end{array}$ & $\begin{array}{l}\text { Lis Ita Patmalasari } \\
\text { (2019) }\end{array}$ \\
\hline 13. & $\begin{array}{l}\text { Variabel independen (bebas) } \\
\text { adalah senam lansia } \\
\text { Variabel dependen (terikat) } \\
\text { adalah tekanan darah }\end{array}$ & $\begin{array}{l}\text { Ada pengaruh senam lansia } \\
\text { terhadap penurunan tekanan darah } \\
\text { pada wanita lansia dengan } \\
\text { hipertensiDi Wilayah Kerja } \\
\text { Puskesmas Banjarsari Metro Utara }\end{array}$ & $\begin{array}{l}\text { Yuli Yantina \& Ajeng } \\
\text { Saputri (2019) Vol.2 } \\
\text { No.1 }\end{array}$ \\
\hline 14. & $\begin{array}{l}\text { Variabel independen (bebas) } \\
\text { adalah senam lansia } \\
\text { Variabel dependen (terikat) } \\
\text { adalah tekanan darah lansia }\end{array}$ & $\begin{array}{l}\text { Senam lansia dapat menurunkan } \\
\text { tekanan darah lansia dengan } \\
\text { hipertensi yang signifikan Pada } \\
\text { Kelompok Senam Lansia Di Desa } \\
\text { Pikat Klungkung }\end{array}$ & $\begin{array}{l}\text { IGN Iswarabhuwana } \\
\text { WP, Ni Luh Nopi } \\
\text { Andayani,dkk (2019) } \\
\text { Vol.7 No.3 }\end{array}$ \\
\hline 15. & $\begin{array}{l}\text { Variabel independen (bebas) } \\
\text { adalah senam hipertensi } \\
\text { Variabel dependen (terikat) } \\
\text { adalah penurunan tekanan } \\
\text { darah }\end{array}$ & $\begin{array}{l}\text { Terdapat pengaruh senam } \\
\text { hipertensi terhadap penurunan } \\
\text { tekanan darah sistolik dan diastolik } \\
\text { pada lansia Di Wilayah Kerja } \\
\text { Puskesmas Bontonyeleng }\end{array}$ & $\begin{array}{l}\text { Zatul Haefa, } \\
\text { Hamdana, } \\
\text { Amirullah (2019) } \\
\text { Vol.4 No.2 }\end{array}$ \\
\hline 16. & $\begin{array}{l}\text { Variabel independen (bebas) } \\
\text { adalah senam hipertensi } \\
\text { Variabel dependen (terikat) } \\
\text { adalah penurunan tekanan } \\
\text { darah }\end{array}$ & $\begin{array}{l}\text { Ada pengaruh yang signifikan } \\
\text { senam lansia terhadap tekanan } \\
\text { darah sistolik dan diastolik lansia } \\
\text { di Wening Wardoyo Ungaran }\end{array}$ & $\begin{array}{l}\text { Suwanti, Puji } \\
\text { Purwaningsih, Umi } \\
\text { Setyoningrum (2019) } \\
\text { Vol.1 No.1 }\end{array}$ \\
\hline 17 & $\begin{array}{l}\text { Variabel independen (bebas) } \\
\text { adalah senam lansia }\end{array}$ & $\begin{array}{l}\text { Senam hipertensi lansia } \\
\text { berpengaruh terhadap tekanan }\end{array}$ & $\begin{array}{l}\text { Purwandari, Kristiana } \\
\text { Puji }\end{array}$ \\
\hline
\end{tabular}


TAHUN [MANUJU: MALAHAYATI NURSING JOURNAL, ISSN CETAK: 2655-2728

\begin{tabular}{|c|c|c|c|}
\hline & $\begin{array}{l}\text { Variabel dependen (terikat) } \\
\text { adalah penurunan tekanan } \\
\text { darah }\end{array}$ & $\begin{array}{l}\text { darah lansia hipertensiDi Kelurahan } \\
\text { Sukoharjo }\end{array}$ & $\begin{array}{l}\text { Suwarno, Siska Ade } \\
(2020) \\
\text { Vol.9 No.2 }\end{array}$ \\
\hline 18. & $\begin{array}{l}\text { Variabel independen (bebas) } \\
\text { adalah senam lansia } \\
\text { Variabel dependen (terikat) } \\
\text { adalah tekanan darah pada } \\
\text { lansia }\end{array}$ & $\begin{array}{l}\text { Ada pengaruh pemberian latihan } \\
\text { senam lansia terhadap penurunan } \\
\text { tekanan darah pada lansia } \\
\text { hipertensi di wilayah kerja } \\
\text { Puskesmas Rappokalling }\end{array}$ & $\begin{array}{l}\text { Najihah \& } \\
\text { Rahmawati Ramli } \\
\text { (2020) Vol.2 No.1 }\end{array}$ \\
\hline 19. & $\begin{array}{l}\text { Variabel independen (bebas) } \\
\text { adalah senam lansia } \\
\text { Variabel dependen (terikat) } \\
\text { adalah penurunan tekanan } \\
\text { darah }\end{array}$ & $\begin{array}{l}\text { Terdapat pengaruh senam lansia } \\
\text { terhadap penurunan tekanan darah } \\
\text { sistolik dan diastolik pada lansia } \\
\text { hipertensi di BPSTW unit Abiyoso } \\
\text { Yogyakarta }\end{array}$ & $\begin{array}{l}\text { Eviyanti, } \\
\text { Heny Noor Wijayanti, } \\
\text { Sitti Khadijah (2021) } \\
\text { Vol.8 No.1 }\end{array}$ \\
\hline 20. & $\begin{array}{l}\text { Variabel independen (bebas) } \\
\text { adalah senam bugar lansia } \\
\text { Variabel dependen (terikat) } \\
\text { adalah penurunan tekanan } \\
\text { darah }\end{array}$ & $\begin{array}{l}\text { Ada perbedaan yang signifikan } \\
\text { antara nilai tekanan darah sistolik } \\
\text { pre test dan post test setelah } \\
\text { dilakukan senam bugar lansia di } \\
\text { Posyandu Lansia Pucangsawit }\end{array}$ & $\begin{array}{l}\text { Irma Mustika Sari \& } \\
\text { Eska Dwi Prajayanti } \\
(2021) \\
\text { Vol.12 No.1 }\end{array}$ \\
\hline
\end{tabular}

Berdasarkan hasil analisis literature review terdapat 20 jurnal yang dinyatakan $\mathrm{Ha}$ atau hipotesis alternatifnya diterima. Dengan adanya pengaruh senam lansia terhadap penurunan tekanan darah pada penderita hipertensi secara signifikan, didapatkan hasil bahwa adanya pengaruh senam lansia terhadap penurunan tekanan darah karena pada gerakan senam lansia mampu meningkatkan aliran darah dan pasokan oksigen, khususnya terhadap otot jantung. Jika melakukan senam secara rutin, maka pembuluh darah akan melebar dan menjadi lebih elastis sehingga tekanan darah akan menurun. Sehingga asumsi dari penelitian (Oswari, 1999 dalam jurnal Mahanani \& Kurnia, 2016) dapat diterima bahwa senam lansia berpengaruh dalam penurunan tekanan darah.

\section{PEMBAHASAN}

\section{Analisis Pengaruh Senam Lansia \\ Terhadap Tekanan Darah Pada Lansia Penderita Hipertensi \\ Berdasarkan analisis 20 jurnal} yang telah di review, dikategorikan 2 jenis terapi non farmakologi yaitu terapi senam lansia sebanyak 10 jurnal dan terapi jalan kaki sebanyak 1 jurnal serta kategori tekanan darah 1 jenis yaitu hipertensi sebanyak 9 jurnal. Sebagian besar menggunakan studi desain Pre Experimental - One Group pre test and post test design dipublikasikan antara tahun 2011 sampai 2021 dan sebagian besar menggunakan jurnal tahun 2019. Bahasa yang digunakan yaitu Bahasa Indonesia.

Hasil analisis dari keseluruhan jurnal inklusi, dapat disimpulkan bahwa semakin bertambahnya usia seseorang maka tekanan darah nya pun akan semakin bertambah. Terutama pada usia lansia, resiko terkena hipertensi akan semakin besar karena disebabkan oleh perubahan fungsi fisiologis yang menurun, sehingga memicu penyakit tidak menular salah satunya yaitu hipertensi menurut asumsi (Araujo, C.L. \& Ceolim, M.F.(2010) dalam jurnal (Lukmana et al., 2020)

Berdasarkan Laporan Nasional Riskesdas (2018), usia lansia yang paling banyak menderita hipertensi yaitu pada usia 75 tahun lebih $(69,53 \%)$ dan lebih di dominasi oleh perempuan $(36,85 \%)$ dibanding dengan laki-laki $(31,34 \%)$.

Hasil penelitian ini sesuai 
dengan teori Hatmanti \& Pratiwi (2015) bahwa hipertensi terjadi akibat obstruksi pada arteri dan kelemahan otot jantung dalam memompa darah. Hal ini disebabkan karena pada usia lanjut terjadi penurunan massa otot, kekuatan dari laju denyut jantung maksimal dan terjadinya peningkatan kapasitas lemak tubuh.

Oleh sebab itu, lansia perlu melakukan aktivitas yang bisa membantu menurunkan tekanan darah salah satunya dengan terapi non farmakologi senam lansia. Berdasarkan karakteristik hasil penelitian didapatkan kategori senam lansia sebesar (50\%), dan terapi jalan kaki sebesar (5\%) serta kategori hipertensi sebesar (45\%).

Menurut Tulak \& Munawira Umar, (2017) Agar aliran darah menjadi lancar dan angka kesakitan hipertensi lansia juga menurun, maka olahraga yang bisa dilakukan oleh lansia dalam menurunkan tekanan darah yaitu dengan melakukan senam lansia. Dilihat dari manfaat senam lansia yaitu melancarkan peredaran darah, memberikan rangsangan yang baik bagi saraf - saraf yang lemah oleh karena itu perlu bagi lansia melakukan senam lansia.

Dalam kategori terapi non farmakologi, penatalaksanaan hipertensi dengan terapi jalan kaki hanya sebesar (5\%) dibandingkan dengan senam lansia. Maka dari itu senam lansia lebih efektif dalam menurunkan tekanan darah dibanding terapi jalan kaki hal ini dikarenakan gerakan senam lansia dapat merangsang peningkatan kekuatan pompa jantung dan membantu melenturkan pembuluh darah sehingga peredaran darah kembali lancar.

Berdasarkan hasil analisis dari 20 jurnal, lansia penderita hipertensi dapat melakukan aktifitas fisik yang bertujuan untuk menurunkan tekanan darah seperti senam lansia (50\%), dan terapi jalan kaki (5\%).Lansia yang melakukan aktivitas fisik tersebut akan dilakukan pengukuran tekanan darah, hasil pengukuran tekanan darah dilakukan perbandingan tingkat efektifitasnya. Didapatkan, hasil perbandingan antara senam lansia dengan berjalan kaki yakni senam lansia lebih efektif dibandingkan dengan terapi jalan kaki alasannya karena pada saat melakukan senam tekanan darah akan naik, dan sebaliknya setelah latihan selesai, tekanan darah akan turun sampai di bawah batas normal yang berlangsung selama $30-120$ menit. Penurunan ini terjadi dikarenakan pembuluh darah mengalami pelebaran dan relaksasi. Apabila dilakukan secara berulangulang, maka penurunan tekanan darah tadi berlangsung lebih lama. Itulah sebabnya, latihan senam lansia secara teratur akan dapat menurunkan tekanan darah pada lansia dengan hipertensi.

\section{KESIMPULAN}

Hipertensi menjadi masalah penyebab kematian nomor satu di dunia setiap tahunnyadan sebagian besar diderita oleh lansia. Prevalensi penderita hipertensi pada lansia mencapai 69,53\% menurut Laporan Riskesdas tahun 2018. Ketidakpatuhan lansia dalam mengkonsumsi obat hipertensi mengakibatkan tekanan darah tetap tinggi, sehingga dilakukan alternativ pengobatan lain dengan teknik non farmakologi yaitu dengan terapi aktivitas fisik seperti senam lansia dan terapi berjalan kaki.

Menurut penelitian yang dilakukan Lis Ita Patmalasari, (2019), hasil analisis uji bivariat menunjukan terdapat perbedaan 
antara tekanan darah sistolik dengan tekanan darah distolik. Didapatkan hasil rata-rata penurunan tekanan darah lebih banyak pada senam lansia dibandingkan jalan kaki hal ini dikarenakan senam lansia dapat membuat pembuluh darah menjadi elastis dan terpelihara. Maka disimpulkan bahwa terdapat perbedaan efektivitas antara jalan kaki dengan senam lansia terhadap tekanan darah lansia dengan hipertensi dimana senam lansia lebih berpengaruh terhadap penurunan tekanan darah.

\section{DAFTAR PUSTAKA}

Agustinus, I., Santoso, E., \& Rahayudi, B. (2018). Klasifikasi Risiko Hipertensi Menggunakan Metode Learning Vector Quantization ( LVQ ). Jurnal Pengembangan Teknologi Informasi Dan Ilmu Komputer (J-PTIIK) Universitas Brawijaya, 2(8), 2947-2955. http://jptiik.ub.ac.id/index.php/jptiik/article/view/1725/654

Aisyiah, Saputri, M. E., \& Laratmase, I. (2020). Pengaruh Senam Lansia Terhadap Penurunan Tekanan Darah Tinggi di Wilayah Kerja Puskesmas Ciputat timur Provinsi Banten. Tersedia dari Repository Fakultas Ilmu kesehatan Universitas Nasional diakses pada tanggal 10/04/2021.

Anwari, M., Vidyawati, R., Salamah, R.dkk. (2018). Pengaruh Senam Anti Hipertensi Lansia Terhadap Penurunan Tekanan Darah Lansia di Desa Kemuningsari Lor Kecamatan Panti Kabupaten Jember. The Indonesian Journal of Health Science, September, 160. https://doi.org/10.32528/ijhs. v0i0.1541
Eviyanti. (2020). Pengaruh Senam Lansia Terhadap Penurunan Tekanan Darah di BPSTW Sleman Yogyakarta 2020 Eviyanti Prodi DIII Kebidanan STIKES Nusantara Lasinrang Pinrang Email: Yantievi869@gmail.com. Junal Kesehatan Luwu Raya, 7(1), 8287.

Eviyanti, E., Wijayanti, H. N., \& Khadijah, S. (2021). Pengaruh Senam Lansia terhadap Penurunan Tekanan Darah pada Lansia. Jurnal Kebidanan Harapan Ibu Pekalongan, 8(1), 18-23.

https://doi.org/10.37402/jurbi dhip.vol8.iss1.117

Fadila, Erida. (2019). Buku Saku Keperawatan Klinik. Cirebon: CV.Confident

Febriati Astuti, Marvia, E., \& Wulandari, S. N. (2020). Pengaruh Senam Lansia Terhadap Perubahan Nyeri Sendi Pada Lansia di Balai Sosial Lanjut Usia (BSLU) Mandalika Mataram. STIKes Mataram, 29(5), 43-49.

Febriyani, M Indika, P., \& Effendi, H. (2018). Pengaruh Latihan Senam Lansia Terhadap Penurunan Tekanan Darah Usia Lanjut. Jurnal Stamina, 1(1), 166-170.

file:///C:/Users/HILMAI 1/App Data/Local/Temp/49-Article Text-60-1-10-20190123.pdf

Haefa, Z., Hamdana, \& Amirullah. (2019). Senam Hipertensi Terhadap Penurunan Tekanan Darah Pada Lansia di Wilayah Kerja Puskesmas Bontonyeleng.Jurnal Kesehatan Panrita Husada, 4(2), 57-68. https: //doi.org/10.37362/jkph .v4i2.141

Hasanudin, Adriyani, V. M., \& Perwiraningtyas, P. (2018). Hubungan Aktivitas Fisik 
dengan Tekanan Darah pada Masyarakat Penderita Hipertensi di Wilayah Tlogosuryo Kelurahan Tlogomas Kecamatan Lowokwaru Kota Malang. Journal Nursing News, 3(1), 787-799.

Hasliani, \& Yustiana, S. (2019). Pengaruh Senam Lansia Terhadap Pasien Hipertensi di Puskesmas Somba Opu Kabupaten Gowa. Jurnal Mitrasehat, Ix(November), 683691.

Hatmanti, N. M., \& Pratiwi, D. (2015). Senam Lansia Mempengaruhi Tekanan Darah Lansia di Puskesmas Kebonsari Surabaya.Journal of Health Sciences, 6(2). https://doi.org/10.33086/jhs.v $6 i 2.40$

Hernawan, T., \& Rosyid, F. N. (2017). Pengaruh Senam Hipertensi Lansia terhadap Penurunan Tekanan Darah Lansia dengan Hipertensi di Panti Wreda Darma Bhakti Kelurahan Pajang Surakarta.Jurnal Kesehatan, 10(1), 26. https://doi.org/10.23917/jurk es.v10i1.5489

Izhar, M. D. (2017). Pengaruh Senam Lansia Terhadap Tekanan Darah di Panti Sosial Tresna Werdha Budi Luhur Jambi.Jurnal Ilmiah Universitas Batanghari Jambi Vol.17 No. 1 Tahun 2017, 17(1), 204-210.

https://scholar.googleusercont ent.com/scholar.bib?q=info:xe RKyYKu78AJ:scholar.google.co $\mathrm{m} /$ \&output=citation\&scisig $=\mathrm{Aa}$ gbfm0aaaaaxorgzwumdmn117kydvlcdtabsak3sg0\&Scisf $=4$ $\& C \mathrm{t}=$ Citation\& $\mathrm{Cd}=3 \& \mathrm{Hl}=\mathrm{Id}$

Kementerian Kesehatan Republik Indonesia. (2018). Laporan Nasional RISKESDAS 2018. Jakarta: Siswanto. Diakses dari http://dinkes.babelprov.go.id/ sites/default/files/dokumen/b ank_data/20181228\%20-

\%20Laporan\%20Riskesdas\%2020 18\%20Nasional-1.pdf. Tanggal 10 April 2021

Kementerian Kesehatan Republik Indonesia. (2019). Hipertensi Penyakit Paling Banyak Diidap Masyarakat. Kemenkes RI. Diakses dari https: / /www.kemkes.go.id/art icle/view/19051700002/hipert ensi-penyakit-paling-banyakdiidap-masyarakat.html. Tanggal 10 April 2021

Liawati, E. (2013). Hubungan Kerutinan Senam Lansia Terhadap Tekanan Darah Lansia Penderita Hipertensi di Posyandu Widodo Makmur Wilayah Kerja Puskesmas Demangan Kota Madiun. Integration of Climate Protection and Cultural Heritage: Aspects in Policy and Development Plans. Free and Hanseatic City of Hamburg, 26(4), 1-37.

Lis Ita Patmalasari. (2019). Perbedaan Jalan Kaki dengan Senam Lansia Terhadap Tekanan Darah pada Lansia Hipertensi di UPTD PSRLU Ciparay Kabupaten Bandung. Tersedia Dari Repository Fakultas Keperawatan Universitas Bhakti Kencana Bandung Diakses Pada Tanggal 02/05/2021

Lukmana, R. A., Pristianto, A., \& Suparno. (2020). Penyuluhan Tentang Senam Lansia untuk Meningkatkan Kualitas Tidur pada Lansia Posyandu Sehati Desa Pauh Menang. Jurnal Pengabdian Masyarakat Multidisiplin, 4(1), 61-66.

M. Noor Ifansyah, Herawati, N. D. (2015). Senam Lansia Terhadap Penurunan Tekanan Darah pada 
Lansia dengan Hipertensi. Jurnal Dk, 3(1), 86-93.

Mahanani, S., \& Kurnia, E. (2016). Pengaruh Senam Lansia Terhadap Tekanan Darah Lansia di Panti Wredha Santo Yoseph Kediri. Jurnal STIKES RS Baptis Kediri, 9(2), 82-89.

Mamitoho, R. F., Sapulete, I. M., \& Pangemanan, D. H. C. (2016). Pengaruh senam lansia terhadap kadar kolesterol total pada lansia di BPLU Senja Cerah Manado.Jurnal E-Biomedik, 4(1).

https: //doi.org/10.35790/ebm .4.1.2016.10845

Najihah, \& Ramli, R. (2020). Senam Lansia Menurunkan Tekanan Darah pada Lansia. Journal of Telenursing (JOTING), 2(1), 11 20.

Nurarif, Amin Huda., Hardhi Kusuma. (2015). Aplikasi Asuhan Keperawatan Berdasarkan Diagnosa Medis dan Nanda NIC-NOC Edisi Revisi Jilid 2. Jogjakarta: Mediaction Publishing Jogjakarta

Purwandari, K. P., \& Suwarno, S. A. (2020). Efektifitas Senam Lansiaterhadap Penurunan Tekanan Darah. Jurnal Keperawatan GSH Vol 9 No 2 Juli 2020 Issn 2088-2734, 9(2), 1-5.

Raharjo, R. D., \& Kumaat, N. A. (2013). Pengaruh Senam Lansia Terhadap Kebugaran Lansia di Panti Werdha Majapahit Mojokerto.Journal of Chemical Information and Modeling, 53(9), 1689-1699.

Riskesdas. (2018). Laporan Riskesdas Nasional 2018 Kemenkes RI. In Laporan Riskesdas Nasional 2018 (p. 120).

Sari, I. M., \& Prajayanti, E. D. (2021). Penurunan Tekanan Darah Melalui Senam Bugar Lansia Pada Lansia Dengan
Hipertensi.Jurnal Ilmu Dan Teknologi Kesehatan, 12(1), 4147.

https://doi.org/10.33666/jitk. v12i1.393

Sartika, D., \& Vebi, W. O. (2020). Efektivitas Senam Lansia (Lanjut Usia) Terhadap Tekanan Darah Pada Lansia Dengan Hipertensi Di Puskesmas Samata Kecamatan Somba Opu Kabupaten Gowa.Jurnal IImiah Kesehatan Diagnosis, 15(1), 1-5. https://doi.org/10.35892/jikd. v15i1.306

Sinta, R., Sri, M., \& Permana, L. I. (2017). Pengaruh Senam Terhadap Tekanan Darah Lansia Dipanti Sosial Tresna Werdha Budi Sejahtera Provinsi Kalimantan Selatan di Banjarbaru.Journal.Stikessuak ainsan.Ac.Id, $\quad 28, \quad$ 1-7. http://journal.stikessuakainsa n.ac.id/index.php/jksi/article/ view/68

Sumartini, N. P., Zulkifli, Z., \& Adhitya, M. A. P. (2019). Pengaruh Senam Hipertensi Lansia Terhadap Tekanan Darah Lansia Dengan Hipertensi Di Wilayah Kerja Puskesmas Cakranegara Kelurahan Turida Tahun 2019.2 Jurnal Keperawatan Terpadu (Integrated Nursing Journal), 1(2), 47. https://doi.org/10.32807/jkt.v $1 i 2.37$

Sumiyarsi, I., Nugraheni, A., dkk. (2021). Pengaruh Tekanan Darah Terhadap Aktivitas Fisik Lansia Effects of Blood Pressure on Physical Activity of the Elderyl. 9(1), 136-141.

Suwanti, S., Purwaningsih, P., dkk. (2019). Pengaruh Senam Terhadap Tekanan Darah Lansia dengan Hipertensi.Jurnal Penelitian Perawat Profesional, 
$1(1)$,

$1-12$.

https://doi.org/10.37287/jppp .v1i1.15

Tarigan, P. B. (2020). Senam Hipertensi Pada Lansia Desa Romangloe Kecamatan Bontomarannu Kabupaten Gowa.Journal of Chemical Information and Modeling, 53(9), 1689-1699.

Tulak, G. T., \& Munawira Umar, D. (2017). Pengaruh Senam Lansia Terhadap Penurunan Tekanan Darah Lansia Penderita Hipertensi Di Puskesmas Wara Palopo. Perspektif, 02(01), 160172.

www.journal.unismuh.ac.id/pe rspektif

Utami, Yulianto, A., \& Wibisono. (2018). Pengaruh Olah Raga Jalan Kaki Terhadap
Peningkatkan Tekanan Darah pada Klien Hipotensi di SMKN Iii Pamekasan.Journals of Ners Community, 09(01), 98-105.

WP, I. I., Andayani, N. L. N., dkk. (2019). Pengaruh Senam Lansia Terhadap Tekanan Darah Lansia dengan Hipertensi Pada Kelompok Senam Lansia di Desa Pikat Klungkung.Jurnal Majalah Ilmiah Fisioterapi Indonesia, 7(3), 83-90.

Yantina, Y., \& Saputri, A. (2019). Pengaruh Senam Lansia Terhadap Tekanan Darah Pada Wanita Lansia dengan Hipertensi di Wilayah Kerja Puskesmas Banjarsari Metro Utara Tahun 2018. Jurnal Farmasi Malahayati, 2(1), 112121. 